\title{
Daily variations of the saccular endolymph and plasma compositions in the turbot Psetta maxima: relationship with the diurnal rhythm in otolith formation
}

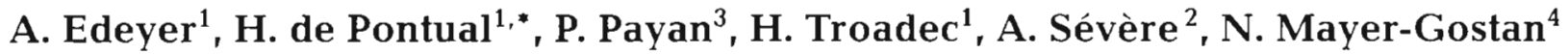 \\ ${ }^{1}$ Laboratoire de Sclérochronologie des Animaux Aquatiques, IFREMER, DRV/RH/LASAA, and ${ }^{2}$ Laboratoire de Physiologie \\ des poissons, IFREMER, DRV/RA, BP 70, 29280 Plouzané, France \\ ${ }^{3}$ Laboratoire de Physiologie et Toxicologie Environnementale EA 2138, and ${ }^{4}$ Laboratoire de Physiologie Cellulaire et \\ Moléculaire UMR CNRS 6548, Université de Nice-Sophia Antipolis, Faculté des Sciences, BP 71, 06108 Nice Cedex 2, France
}

\begin{abstract}
We studied the circadian variations of the ionic composition ([Na $\left.\left.{ }^{*}\right],\left[\mathrm{K}^{+}\right],\left[\mathrm{Cl}^{-}\right]\right)$, total $\mathrm{CO}_{2}$ ([tot $\left.\mathrm{CO}_{2}\right]$ ), and protein concentration ([protein]) in the plasma and endolymph in the distal and proximal sides of the sacculus in the turbot Psetta maxima. Daily variations in total plasma calcium ([tot Ca]) were also recorded. Significant diurnal fluctuations occurred in most parameters and the spatial heterogeneity of the endolymph composition was maintained throughout a $24 \mathrm{~h}$ period. The main parameters implicated in otolith calcification, endolymph [tot $\mathrm{CO}_{2}$ ] and endolymph [protein], fluctuated diurnally. [tot $\mathrm{CO}_{2}$ ] was highest and [protein] lowest at night; the relative concentrations were reversed during the day. The inverse, alternating relationship of maximal and minimal [tot $\mathrm{CO}_{2}$ ] and [protein] implies that calcium carbonate and organic matrix rates of deposition vary in antiphase. We therefore propose that in the turbot $P$. maxima, in autumn, the incremental zone (L-zone) is formed at night whereas the discontinuous zone (D-zone) is formed during the daytime.
\end{abstract}

KEY WORDS: Daily cycle $\cdot$ Endolymph $\cdot$ Otolith $\cdot$ Chemical composition $\cdot$ Teleost

\section{INTRODUCTION}

Teleost otoliths are calcareous structures involved in fish balancing and hearing processes (Fay 1980. Gauldie \& Radtke 1990). They are composed of calcium carbonate, mainly in the mineral form of aragonite (Carlstrom 1963) and an organic matrix in which acidic amino acids dominate (Degens et al. 1969). Accretion occurs by successive depositions of incremental (calcium dominant) and discontinuous (matrix dominant) zones (Watabe et al. 1982, Morales-Nin 1987). In many fish the deposition of these 2 layers occurs throughout the day, producing a recognisable

·Corresponding author. E-mail: pontual@ifremer.fr daily increment (Pannella 1980). Since the structure and chemical composition of otoliths is scarcely modified after deposition, they can be considered as biological archives and are commonly used for age and growth estimations (Campana \& Neilson 1985). They also allow studies on stock discrimination of exploited populations (Campana et al. 1995, Severin et al. 1995) and permit the characterisation of certain events in the life cycle (Kalish 1992, Otake et al. 1994, Secor et al. 1995).

In relation to the cyclic formation of otolith increments, several studies have suggested the importance of photoperiodicity (Taubert \& Coble 1977, Tanaka et al. 1981, Radtke \& Dean 1982). Tanaka et al. (1981) demonstrated that in Tilapia nilotica (L.), the order of formation of the incremental zone (L-zone) and discon- 
tinuous zone (D-zone) was photoperiod dependent, since a reversal of the light-dark cycle induced a reversal in the order of the 2 layers. It has also been shown that the daily rate of increment formation is maintained in juvenile fish after transfer to constant light (Campana 1984, Wright et al. 1991) or darkness (Radtke \& Dean 1982). Mugiya (1987) and Wright et al. (1992) suggested that the rhythm in otolith calcification is controlled by a circadian variation in plasma chemistry, since they found that during the dark period there is a parallel decline in otolith calcification and total and free plasma calcium concentrations. Furthermore, Mugiya (1984) found a seasonal reversal in the rhythm of otolith calcification associated with a reversal in the plasma calcium cycle.

Fish have, in each inner ear, 3 otoliths bathed in endolymph within a sac. The largest otolith, called the sagitta, is located within the sacculus. Although the main characteristics of the endolymph have been described earlier (Mugiya \& Takahashi 1985), it is only recently that endolymph samples have been analysed individually (Payan et al. 1997). It has been suggested that otolith biocalcification is related to endolymph composition (Romanek \& Gauldie 1996). In a recent work Payan et al. (1999) showed that inside the sacculus the endolymph has a lack of spatial uniformity of its chemical composition, probably due to the presence of several types of ionocyte population on the 2 sides of the saccular epithelium which are probably concerned with active ion transport (Mayer-Gostan et al. 1997). Payan et al. (1999) proposed that the spatial heterogeneity of some parameters in the endolymph is necessary for the mineralization of the otolith. They suggested that $\mathrm{CaCO}_{3}$ deposition is initiated on the proximal side of the otolith When $\mathrm{CaCO}_{3}$ is generated, a $\mathrm{H}^{+}$is produced which must be removed. As the saccular opithelium is relatively far from the mineralization site, the proximo-distal bicarbonate gradient would locally buffer the $\mathrm{H}^{*}$ and help calcification to proceed all around the otolith. These authors also demonstrated a close relationship between the spatial heterogeneity in the $\mathrm{K}$ concentration of the endolymph and that of the otolith. Very little research has been carried out on daily variations in endolymph chemistry. Mugiya \& Takahashi (1985) found simultaneous diurnal variations in plasma and endolymph [ tot $\mathrm{CO}_{2}$ ]

The present study was undertaken to determine, by sampling both distal and proximal zones, whether this enumbinph heterogencity is maintained throughout the diumal cycle. Rhythms of otolith calcification reflect the chemical compositions of plasma and endolymph during the daily cycle. Diurnal profiles of plasma and endolymph concentrations of protein, carbon dioxide, sodium, potassium and chlorine, and also plasma calcium concentration were therefore made.

\section{MATERIALS AND METHODS}

The experiments were carried out over the 2 days of 22 to 23 October 1997 , on turbot $P_{\text {setta maxima reared }}$ in running seawater at $18^{\circ} \mathrm{C}$, and subjected to a photoperiodicity of $13 \mathrm{~h} \mathrm{light}$ to $11 \mathrm{~h}$ darkness (the light period starting at 07:00 h). Turbot weighing about 400 to $500 \mathrm{~g}$ were fed once a day in the morning (around $10: 00 \mathrm{~h}$ ) but food was withheld $24 \mathrm{~h}$ prior to the beginning of the experiments. The fish were acclimated to the experimental conditions $3 \mathrm{wk}$ before sampling

Batches of 6 fish netted from the tank were taken at 3 h intervals. Blood was rapidly collected from the caudal vessels and centrifuged, the separated plasma being kept in a refrigerator until analysis. The techniques of endolymph and plasma sampling have been described previously (Payan et al. 1997, 1999). Briefly, after decapitating the fish and exposing the inner ear, 2 samples of endolymph of about $5 \mu$ leach were taken in the left sacculus using calibrated capillaries. The right sacculus was sampled in the same way immediately after The sample withdrawn near the macula will be designed as 'proximal' while that from the opposite side will be designed as 'distal' The endolymph contained in capillaries was stored in a refrigerator and analysed shortly after The right sacculus samples wer: used to measure [protein], $\left[\mathrm{Na}^{+}\right],\left[\mathrm{Cl}^{-}\right]$and $\left[\mathrm{K}^{+}\right]$, while [tot $\mathrm{CO}_{2}$ ] was measured on samples of the left sacculus.

Plasma and endolymph were analysed as described in Payan et al. (1997). [Na $]$ and $\left[\mathrm{K}^{+}\right]$were measured by flame photometry. [tot $\mathrm{Ca},\left[\mathrm{Cl}^{-}\right]$, [tot $\mathrm{CO}_{2}$ ] and [protein] were measured by spectrophotometry using Sigma kits for the first 3 parameters and Commassie blue for proteins with BSA (bovin serum albumin) as standard. As fish were not anaesthetised in these experiments the level of stress and its variability were estimated by measuring the plasma cortisol concentrations by radioimmunoassay.

Data are expressed as means and standard errors. The diurnal cycles are analysed using univariate ANOVA after having checked variable normality. In case of deviation, a Kruskall and Wallis test was employed. A contrast analysis was used for the comparison of individual peaks or troughs with the initial value at 14:00 h. Signiticance was attributed at $p<0.05$.

\section{RFSIIITS}

Plasma cortisol concentrations (mean $42.8 \pm 5.32$ ng $\mathrm{ml}^{-1}$ ) did not vary significantly during the diurnal cycle. Values at the beginning (14:00 h) and at the end of experiments (14:00 h following day) were not significantly different. 
To clarify the variations of endolymph composition and their relationships to those of plasma, the data for the 2 fluids are presented on the same graphs. First, the initial and final concentrations measured at the same hour of the day were compared, and although some variation was observed, none of the differences were significant. Statistical comparisons of the data against the reference initial value (corresponding to the midpoint of the daylight period) were made, except where mentioned.

Fig. 1 shows the daily variations of the concentrations of monovalent ions in plasma and endolymph (distal and proximal). $\left[\mathrm{Na}^{+}\right]$did not vary simultaneously in plasma and endolymph. Although the low levels occurred during the dark period in both fluids, the plasma concentration showed a significant minimum at 23:00 h ( $p=0.004)$, whereas that of the distal endolymph was at $05: 00 \mathrm{~h}(\mathrm{p}=0.003)$. Proximal endolymph $\left[\mathrm{Na}^{+}\right]$remained roughly stable throughout the cycle. There was no significant difference between the $\left[\mathrm{Na}^{+}\right]$ of the proximal and distal endolymphs. Plasma $\left[\mathrm{K}^{+}\right]$ variations were more or less similar to those of plasma $\left[\mathrm{Na}^{+}\right]$with low levels during the dark period and characterised by a significant minimum at 23:00 h (p < $0.0001)$. There were no corresponding variations of proximal and distal endolymph $\left[\mathrm{K}^{+}\right]$which fluctuated non-significantly around their means. The difference between proximal and distal endolymph $\left[\mathrm{K}^{+}\right]$was maintained throughout the cycle. $\left[\mathrm{Cl}^{-}\right]$varied simultaneously in plasma and distal endolymph. However, plasma $\left[\mathrm{Cl}^{-}\right]$fell to a significant minimum at $20: 00 \mathrm{~h}$ $(p=0.020)$ whereas that of the distal endolymph was at 05:00 h $(\mathrm{p}=0.004)$. No corresponding variations were seen in the proximal endolymph $\left[\mathrm{Cl}^{-}\right]$.

Fig. 2 shows the diurnal variations of the main parameter contents involved in otolith calcification. Plasma [tot $\mathrm{Ca}$ ] values were high and stable between 20:00 h and 8:00 h (dark period) and significantly different from the initial concentration. Plasma [tot $\mathrm{Ca}$ ] and plasma [tot $\mathrm{CO}_{2}$ ] show synchronous variations with a significant positive correlation $(p=0.006)$. [tot $\mathrm{Ca}$ ] in the endolymph were not measured because too little endolymph could be sampled. In the 2 fluids, [tot $\mathrm{CO}_{2}$ ] varied simultaneously with high levels during the dark period (significant maxima at 05:00 h, with $\mathrm{p}<0.0001$, $p=0.006$, and $p=0.025$ for plasma, proximal endolymph and distal endolymph values respectively) whereas the low levels observed during the light period were not synchronous (minimum at 14:00 h in plasma and at 17:00 $\mathrm{h}$ in endolymph). In both plasma and proximal endolymph, the magnitude of the variations of [tot $\mathrm{CO}_{2}$ ] between the extreme values was substantial ( $81 \%$ for both media) during the $24 \mathrm{~h}$ period whereas it was only $47 \%$ in the distal endolymph. It is noteworthy that a difference of $3 \mathrm{mM}$ between the proximal and distal sides, within the sacculus, was maintained throughout the experiment. Plasma [proteinl appeared to decline slightly during the $24 \mathrm{~h}$ period and were characterised by 2 significant minima, at $23: 00 \mathrm{~h}(\mathrm{p}<0.001)$ and $11: 00 \mathrm{~h}(\mathrm{p}<0.001)$. Endolymph [protein] clearly decreased during the dark period particularly in the proximal side. Between 20:00 and 02:00 h the magnitude of variation was 65 and $58 \%$ for proximal and distal sides, respectively. Nevertheless, a large scatter of the values obscured this phenomenon and none of the mean values was signifi-

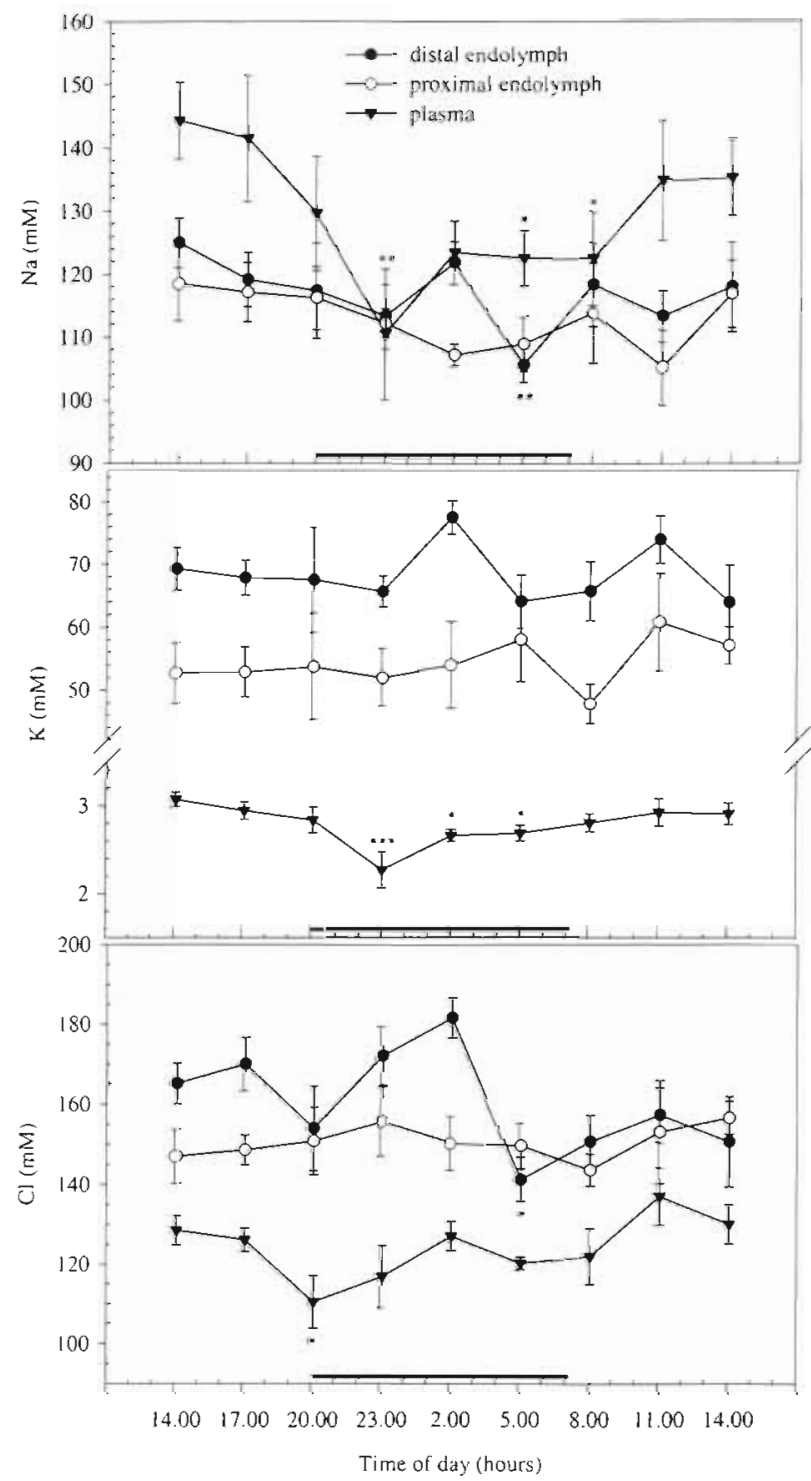

Fig. 1. Psetta maxima. Diurnal variations of $\left[\mathrm{Na}^{+}\right],\left[\mathrm{K}^{+}\right]$and $\left[\mathrm{Cl}^{-}\right]$in plasma ( $\mathbf{v}$, proximal endolymph (O) and distal endolymph (•) in the turbot. Each point represents the mean \pm SE of 6 fish. The dark horizontal bars indicate the nocturnal period. (Individual peaks or troughs were compared with the initial value at $14: 00 \mathrm{~h} . " \mathrm{p}<0.05 ;{ }^{*} \mathrm{p}<0.01 ;{ }^{*} \mathrm{p} p<0.001$ ) 


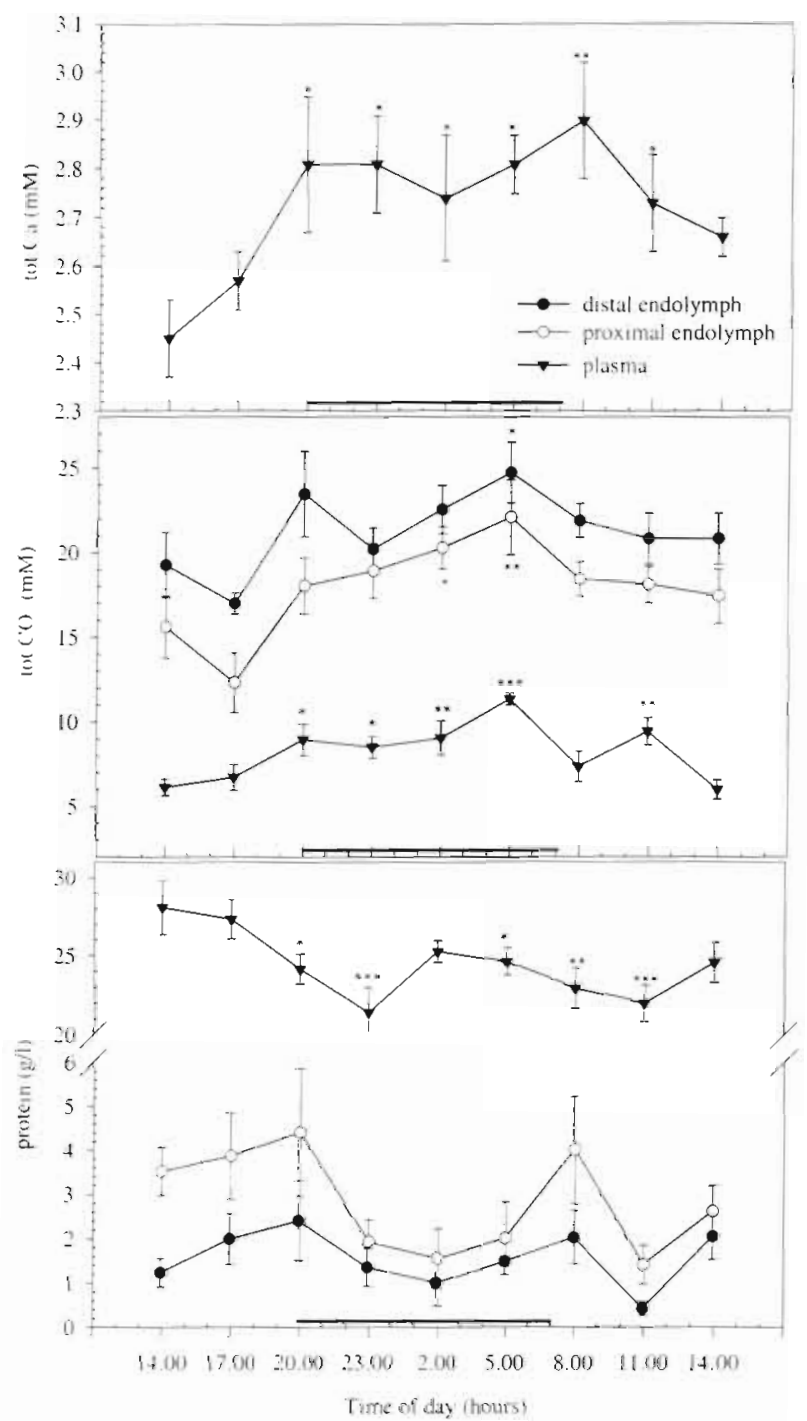

Fig. 2. Psetta maxima. Diurnal variations of [tot $\mathrm{Ca}$ ], [tot $\mathrm{CO}_{2}$ ], and [protein] in plasma ( $\mathbf{v}$ ), proximal endolymph (o) and distal endolymph (•) in the turbot. Each point represents the mean $\pm \mathrm{SE}$ of 6 fish. The dark horizontal bars indicate the nocturnal period. Individual peaks or troughs were compared with the initial value at $14: 00 \mathrm{~h} . \mathrm{p}<0.05 ; \cdots p<0.01 ; \cdots p<0.0011$

cantly different from the initial. However, a significant difference $(p=0.005)$ was observed between the pooled samples of proximal endolymph at 14:00, 1.7:00 and $20: 00 \mathrm{~h}$ compared with those at 23:00,02:00 and 05:00 h. The time profile of endolymph [protein] shows a second minimum at 11:00 h concomitant with a significunt minimum in plasma [protein] porhaps in relation to the time at which fish were usually fed. The proximo-distai [proteinj gradient was maintained throughout the cycle. Time variations of endolymph [protein] appeared to he reversed relative to those of [tot $\mathrm{CO}_{2}$ ] and, although these parameters were measured on 2 different sacculi (see above), they showed a

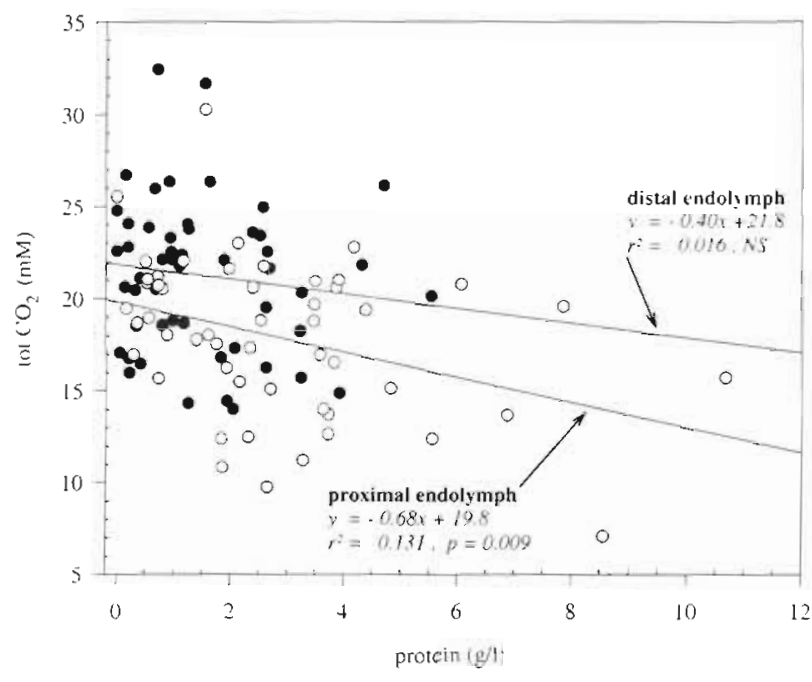

Fig. 3. Psetta maxima. Relationships between $\left[\right.$ tot $\mathrm{CO}_{2}$ ] and [protein] of saccular endalymph, on proximal (O) and distal (-) sides

significant negative correlation $(p=0.009)$ in the proximal endolymph although it was not significant in the distal endolymph (Fig. 3).

$\left[\mathrm{Na}^{+}\right],\left[\mathrm{K}^{+}\right],\left[\mathrm{Cl}^{-}\right]$and $[$protein] were measured in the same sacculus, permitting the relationships between these different parameters to be evaluated. There were significant negative linear regressions of $\left[\mathrm{K}^{+}\right]$and $\left[\mathrm{Cl}^{-}\right]$compared with [protein] (data not shown) The relationships observed during the light period were preserved during the dark in spite of a lower [protein] during the latter. No correlation between endolymph $\left[\mathrm{Na}^{\top}\right]$ and endolymph [protein] was observed irrespective of side.

\section{DISCUSSION}

\section{Could stress have influenced the experimental results?}

In experiments in which samples are taken regularly over a period, stress via internal factors could either obscure or amplify the true cyclic physiological changes being studied. Björnsson et al. (1989), for example, showed that plasma levels of calcium increased significantly from the first to the tenth fish sampled and that the slopes of the linear regressions were similar in freshwater and seawater animals. The cortisol level is gerierally roncirered to be a good indicator of stress in fish. In the present study, cortisol concentrations were above the resting level, which is known to be very low in turbot (Waring et al. 1996. Person-Le Ruyet pers. comm.), indicating a stress which has already been recorded in turbot after confinement (Waring et al. 1996). The physical stress encountered 
in the present study was probably complex: exposure to air before bleeding was generally brief (about $60 \mathrm{~s}$ ) and all fish were similarly treated. We suggest that the observed high cortisol level was the result of the inevitable chasing and netting of the fish and the fact that they were not anaesthetised. This could explain the magnitude of the standard errors due to individual variability. Nycthemeral variations of cortisol have been reported in freshwater fish by Pickering \& Pottinger (1983) and Gomez et al. (1996), who concluded that cortisol increases are intrinsic phenomena not caused by stress. To our knowledge similar studies have not been made with seawater fish. However, as the cortisol values did not vary significantly over the experimental period, we can assume that this factor did not bias the results.

\section{Monovalent ion variations in plasma and endolymph}

There are few studies of circadian variations in various blood and endolymph components in seawater adapted fish. In the endolymph, they only concerned a few parameters which were generally measured in pooled samples from different individuals. The present study is the first to analyse individual endolymph ionic compositions over a diurnal cycle by taking 2 samples from each sacculus.

Our results show diurnal fluctuations of plasma osmotic composition which are in agreement with those of Audet et al. (1993), although these authors also recorded important seasonal variations as well as species differences. In our experiments monovalent ion concentrations were lower during the dark period. We suggest that this is related to a lower level of activity at night. There are various ways to explain ion circadian variations, such as water loss or the reduction at night of passive ion influxes through the gills, probably associated with reduced drinking of seawater.

Individual ionic concentrations varied differently in endolymph and plasma. $\left[\mathrm{K}^{+}\right]$was significantly lower in the plasma at night but not in the endolymph, suggesting that endolymph $\left[\mathrm{K}^{+}\right]$does not directly depend on plasma $\left[\mathrm{K}^{+}\right]$and that its transfer through the saccular epithelium is controlled. The $[\mathrm{NaCl}]$ variations in the distal region of the endolymph reflected those of the plasma but to a lesser degree, whereas in the proximal region $[\mathrm{NaCl}]$ did not vary significantly. This result corroborates the hypothesis that $\mathrm{Na}^{+}$assumes a role in the mechanically sensitive transduction mechanism (Payan et al. 1999) which should remain functional throughout the daily cycle. Two different types of ionocyte have been observed in the saccular epithelium in the proximal and distal zones, respectively (Mayer-
Gostan et al. 1997). Although their specific relation to ion transport and regulation has not been demonstrated yet, they are undoubtedly involved in the movements of the monovalent ions which appear to maintain a stable environment on the proximal side around the sensorial cells of the macula.

\section{[tot $\mathrm{Ca}$ ], [tot $\mathrm{CO}_{2}$ ] and [protein] variations in plasma and endolymph}

Although calcium concentration is high in seawater, seawater fishes maintain a high (inside positive) transepithelial potential across the branchial epithelium (Maetz \& Bornancin 1975) which is higher than the equilibrium potential for $\mathrm{Ca}^{2+}$; calcium entry through the gills must therefore be an active process which takes place via the transcellular route. The rate of gill calcium transport has been shown to vary following different cycles. For instance, gill calcium transport monitored 3 times weekly for 2 mo showed a $14 \mathrm{~d}$ cyclical pattern (Wagner et al. 1993), which in salmonids has been considered to be related to the cyclic pattern of weight gain (Wagner \& Mckeown 1985). Tahara \& Mugiya (1996) observed a diurnal variation in the branchial calcium uptake of rainbow trout, similar to that of plasma [tot Ca] (Mugiya \& Oka 1991). To our knowledge, no circadian [tot $\mathrm{Ca}$ ] cycle in the plasma has been recorded in seawater fish. The present study clearly suggests that such a cycle exists in turbot $P$ setta maxima, at least in the autumn. More experiments are needed to determine if there is a seasonal reversal of the plasma [tot Ca] cycle similar to that observed by Mugiya (1984). Although endolymph [tot Ca] was not measured in the present study, there are arguments (see below) for considering that plasma [tot $\mathrm{Ca}$ ] variations rapidly induce similar variations in the endolymph.

Our results agree with a previous report of diurnal variations of [tot $\mathrm{CO}_{2}$ ] in plasma and saccular endolymph (Mugiya \& Takahashi 1985). However, nothing has yet been published concerning endolymph (protein] time variations. Our results showed a considerable depletion of endolymph [protein] during the dark period. The magnitude of these changes cannot simply be explained by the amount of protein deposited as matrix on the otolith since the matrix deposit per day is much smaller than the decrease observed (there is an approximate deposition of $20 \mathrm{ng} \mathrm{d}^{-1}$ while the decrease observed in the endolymph is of the order of $\mu \mathrm{g} \mathrm{d}^{-1}$ ). Thus the decrease observed during the dark period could probably result from proteolysis potentially associated with a reduced process of synthesis and secretion. This hypothesis is in agreement with the existence of phases of activity/inactivity in protein biosynthesis and deposition already suggested by Mugiya (1987). 
Moreover, the diurnal variations of [protein] and [tot $\mathrm{CO}_{2}$ ] in the endolymph imply that calcium carbonate and organic matrix deposition rates vary in antiphase. The simultaneous variations in plasma and endolymph (on both proximal and distal sides) for some of the analysed parameters imply a close relationship between these 2 compartments. However it is not clear whether the variations depend on the plasma parameters alone or whether the saccular epithelium, which is known to be complex (Mayer-Gostan et al. 1997. Takagi 1997, Pisam et al. 1998), responds directly to specific hormonal controls which themselves show diurnal rhythms. In point of fact, both mechanisms are probably involved

\section{Maintenance of the gradient}

Payan et al. (1999) showed that some of the components of endolymph are not uniformly distributed. In the present study, the differences between proximal and distal $\left[\mathrm{K}^{+}\right]$, [tot $\left.\mathrm{CO}_{2}\right]$ and [protein] appeared to be maintained during the diurnal cycle. Moreover, the relationships between [protein] and monovalent ions urre similar to those described by Payan et al. (1999), and the correlations were concordant during the 2 periods (light and dark), indicating that the gradients of chemical components are maintained throughout the cycle. Payan et al. (1999) proposed that the [tot $\mathrm{CO}_{2}$ and [protein] gradients in the endolymph are involved in otolith growth and could explain the asymmetrical shape of otoliths. Actually, the decreasing proximo-distal gradient in the [protenn] endolymph would favor a greater matrix deposition on the proximal side of the otolith, resulting in differential otolith growth. The [protein] gradient is the consequence of the distribution of the various cell types in the saccular epithelium since it has been shown that the cells secreting organic material are located around the macula and in the proximal zone (Pisam et al. 1998. Takagi \& Takahashi 1999j. However, the present results do not afford any conclusion concerning the specific proteins of the otolith organic matrix.

\section{Relationship between endolymph concentration rhythms and daily ofolith increments}

The inverse relationchip batween the diurnal thythme of [tot $\left.\mathrm{CO}_{2}\right]$ and [protein] found in the endolymph in the present study strongly suggests the occurrence of alternating phases of otolith calcification ( $L$-zone formation) and organic matrix deposition (D-zone formation) on the otoliths: this is consistent with previous findings (Tanaka et al. 1981. Watabe et al. 1982,
Mugiya 1987). A decrease of [tot $\mathrm{CO}_{2}$ ] in the endolymph has been observed after starvation (Payan et al 1998), and the induced change in endolymph alkalinity has been related to a reduced rate of otolith growth in fasting fishes (Molony \& Choat 1990, Umezawa \& Tsukamoto 1991), corresponding to the reduction in calcium deposition observed by Mugiya \& Oka (1991). The decrease of [tot $\mathrm{CO}_{2}$ ] recorded in the present work was of the same order of magnitude and took place during the light periods, suggesting that mineralisation of the otolith occurred during the dark period. We were not able to measure endolymph |tot Ca], however the coincidence between the rise of plasma [tot Ca] and the decrease of plasma [protein], observed during the dark period, would presumably imply a nocturnal increase in plasma protein-free Ca $\left(\left[\mathrm{Ca}^{2+}\right]\right)$. Moreover, investigations on the isolated sacculus indicated that the endolymph $\left[\mathrm{Ca}^{2+}\right]$ is dependent on a transcellular active transport in the saccular epithelium which is sensitive to plasma $\left[\mathrm{Ca}^{2+}\right]$ (Mugiya \& Yoshida 1995). If that is also true in the turbot, a nocturnal increase in plasma [tot $\mathrm{Ca}$ ] would be expected to induce a nocturnal increase in endolymph [tot $\mathrm{Ca}$ ]. Finally, some authors have reported a parallel decline in plasma [tot $\mathrm{Ca}$ ] and plasma $\left[\mathrm{Ca}^{2+}\right]$ and otolith calcification in goldfish (Mugiya et al. 1981), rainbow trout (Mugiya 1984, Mugiya \& Oka 1991) and salmon parr (Wright et al. 1992). These arguments support our hypothesis that endolymph $\left[\mathrm{Ca}^{2+}\right]$ would have been greater during the dark period when $\left[\right.$ tot $\mathrm{CO}_{2}$ | was high and [protein] low. Such results lead us to suggest that, in Psetta maxima in the autumn, L-zones and D-zones are formed during the dark periods and light periods, respectively. Several studies have shown the opposite, with the mineral-rich zone of the otolith formed during the light period (Mugiya 1987. Wright et al 1992, Zhang \& Runham 1992) However, Mugiya (1984) found a seasonal reversal in the rhythm of otolith calcification associated with a reversal in the plasma [tot $\mathrm{Ca}$ ] cycle. Further experiments are needed to determine whether the present results are specific to $P$. maxima or if there is also, in this species, a reversal rhythm with respect to the season.

The mechanisms which regulate otolith calcification are not yet fully elucidated. Wright (1991) demonstrated that the soluble matrix of salmon otoliths contains a glycoprotein capable of inhibiting calcification in vitro, even after crystallisation has begun. ConseInently, the serretion of this protein into the endolymph would be expected to affect the rate of otolith mineralisation. Indeed diurnal variations in this protein secretion may periodically limit otolith mineralisation and explain the formation of the mineral deficient layer. Further investigation of endolymph protein characterisation is required. 
Acknowledgements. This study was supported by IFREMER and A.E. is a recipient of a grant from IFREMER and the Brittany district. We are indebted to Mrs B. Maetz for correcting the manuscript.

\section{LITERATURE CITED}

Audet C, Besner M, Munro J, Dutil JD (1993) Seasonal and diel variations of various blood parameters in Atlantic cod (Gadus morhua) and American plaice (Hippoglossoides platessoides). Can J Zool 71:611-618

Björnsson BTh, Young G, Lin RJ, Deftos LJ, Bern HA (1989) Smoltification and seawater adaptation in cohosalmon (Oncorhynchus kisutch): plasma calcium regulation, osmoregulation, and calcitonin. Gen Comp Endocrinol 74: $346-354$

Campana SE (1984) Interactive effects of age and environmental modifiers on the production of daily growth increments in the otoliths of plainfin midshipman, Porichthys notatus. Fish Bull US 82:165-177

Campana SE, Neilson JD (1985) Microstructure of fish otoliths. Can J Fish Aquat Sci 42:1014-1032

Campana SE, Gagné JA, McLaren J (1995) Elemental fingerprinting of fish otoliths using ID-ICPMS. Mar Ecol Prog Ser 122:115-120

Carlstrom D (1963) A crystallographic study of vertebrate otoliths. Biol Bull 125:441-463

Degens ET, Deuser WG, Haedrich RL (1969) Molecular structure and composition of fish otoliths. Mar Biol 2:105-113

Fay RR (1980) The goldfish ear codes the axis of acoustic particle motion in three dimensions. Science 225:951-963

Gauldie RW, Radtke RL (1990) Using the physical dimensions of the semicircular canal as a probe to evaluate inner ear function in fishes. Comp Biochem Physiol 96A(1):199-203

Gomez JM, Boujard T, Fostier A, LeBail PY (1996) Characterization of growth hormone nycthemeral plasma profiles in catheterized rainbow trout (Oncorhynchus mykiss). J Exp Zool 274:171-180

Kalish JM (1992) Formation of a stress-induced chemical check in fish otoliths. J Exp Mar Biol Ecol 162:265-277

Maetz J, Bornancin M (1975) Biochemical and biophysical aspects of salt excretion by chloride cells in teleosts. Fortschr Zool 23:322-362

Mayer-Gostan N, Kossman H, Watrin A, Payan P, Boeuf G (1997) Distribution of ionocytes in the saccular epithelium of the inner ear of two teleosts (Oncorhynchus mykiss and Scophthalmus maximus). Cell Tissue Res 480:1-9

Molony BW, Choat $\mathrm{JH}$ (1990) Otolith increment widths and somatic growth rate: the presence of a time-lag. J Fish Biol $37: 541-551$

Morales-Nin B (1987) Ultrastructure of the organic and inorganic constituents of the otoliths of the sea bass. In: Summerfelt RC, Hall GE (eds) The age and growth of fish. Iowa State University Press, Ames, p 331-344

Mugiya Y (1984) Diurnal rhythm in otolith formation in the rainbow trout, Salmo gairdneri: seasonal reversal of the rhythm in relation to plasma calcium concentrations. Comp Biochem Physiol 78A(2):289-293

Mugiya Y (1987) Phase difference between calcification and organic matrix formation in the diurnal growth of otoliths in the rainbow trout, Salmo gairdneri. Fish Bull 85(3): $395-401$

Mugiya $Y$, Oka $H$ (1991) Biochemical relationship between otolith and somatic growth in the rainbow trout Oncorhynchus mykiss: consequence of starvation, resumed feeding, and diel variations. Fish Bull 89:239-245
Mugiya Y, Takahashi K (1985) Chemical properties of the saccular endolymph in the rainbow trout, Salmo gairdneri. Bull Fac Fish Hokkaido Univ 36(2):57-63

Mugiya Y, Yoshida M (1995) Effects of calcium antagonists and other metabolic modulators on in vitro calcium deposition on otoliths in the rainbow trout Oncorhynchus mykiss. Fish Sci 61(6):1026-1030

Mugiya Y, Watabe N, Yamada J, Dean JM, Dunkelberger DG, Shimizu M (1981) Diurnal rhythm in otolith formation in the goldfish, Carassius auratus. Comp Biochem Physiol 68A:659-662

Otake T, Ishii T, Nakahara $M$, Nakamura R (1994) Drastıc changes in otolith strontium/calcium ratios in leptocephali and glass eels of Japanese eel Anguilla japonica. Mar Ecol Prog Ser 112:189-193

Pannella G (1980) Growth pattern in fish sagittae. In: Rhoads DC, Lutz RA (eds) Skeletal growth of aquatic organisms: biological records of environmental change, Plenum Press, New York, p 519-560

Payan P, Kossman H, Watrin A, Mayer-Gostan N, Boeuf G (1997) Ionic composition of endolymph in teleosts: origin and importance of endolymph alkalinity. J Exp Biol 200 : 1905-1912

Payan P, Borelli G, Boeuf G, Mayer-Gostan N (1998) Relationship between otolith and somatic growths: consequence of starvation on acid-base balance in plasma and endolymph in the rainbow trout Oncorhynchus mykiss. Fish Physiol Biochem 19:35-41

Payan P, Edeyer A, de Pontual H, Borelli G, Boeuf G, MayerGostan N (1999) Chenical composition of saccular endolymph and otolith in fish inner ear: lack of spatıal uniformity. Am J Physiol 46:R1.23-R131

Pickering AD, Pottinger TG (1983) Seasonal and diel changes in plasma cortisol levels of the brown trout, Salmo trutta $\mathrm{L}$ Gen Comp Endocrinol 49:232-239

Pisam M, Payan P, Le Moal C, Edeyer A, Boeuf G, MayerGostan N (1998) Ultrastructural study of the saccular epithelium of the inner ear of two teleosts (Oncorhynchus mykiss and Psetta maxima). Cell Tiss Res 294:261-270

Radtke RL, Dean JM (1982) Increment formation in the embryos, larvae and juveniles of the mummichog, Fundulus heteroclitus. Fish Bull US 80:41-55

Romanek CS, Gauldie RW (1996) A predictive model of otolith growth in fish based on the chemistry of the endolymph Comp Biochem Physiol 114A:71-79

Secor DH, Henderson-Arzapalo A, Piccoli PM (1995) Can otolith microchemistry chart patterns of migration and habitat utilization in anadromous fishes? J Exp Mar Biol Ecol 192:15-33

Severin KP, Carroll J, Norcross BL (1995) Electron microprobe analysis of juvenile walleye pollock, Theragra chalcogramma, otoliths from Alaska: a pilot stock separation study. Environ Biol Fish 43:269-283

Tahara D, Mugiya Y (1996) Diel variation in branchial calcium uptake by the rainbow trout. J Fish Biol 49:1034-1037

Takagi Y (1997) Meshwork arrangement of mitochondriarich, $\mathrm{Na}^{+}-\mathrm{K}^{*}$-ATPase rich cells in the saccular epithelium of rainbow trout (Oncorhynchus mykiss) inner ear. Anat $\operatorname{Rec} 248: 483-489$

Takagi Y, Takahashi A (1999) Characterization of otolith soluble-matrix producing cells in the saccular epithelium of rainbow trout (Oncorhynchus mykiss) inner ear. Anat Rec 254:322-329

Tanaka K, Mugiya Y, Yamada J (1981) Effects of photoperiod and feeding on daily growth patterns in otoliths of juvenile Tilapia nilotica. Fish Bull 79(3):459-466

Taubert BD, Coble DW (1977) Daily rings in otoliths of three 
species of Lepomis and Tilapia mossambica. J Fish Res Bd Can 34:332-340

Umezawa A, Tsukamolo K (1991) Factors influencing otolith increment formation in Japanese eel, Anguilla japonica T \& S, elvers. J Fish Biol 39:211-223

Wagner GF, Mckeown BA (1985) Cyclical growth in juvenile rainbow trout, Salmo gairdneri. Can J Zool 63(10): $2473-2474$

Wagner GF, Fargher RC, Milliken C, McKeown BA, Copp DH (1993) The gill calcum transport cycle in rainbow trout is correlated with plasma levels of bioactive, not immunoreactive, stanniocalcin. Mol Cell Endocrinol 93:185-191

Waring CP. Stagg RM. Poxton MG (1996) Physiological responses to handling in the turbot. J Fish Biol 48:161-173 Watabe N, Tanaka K, Yamada J, Dean JM (1982) Scanning electron microscope observations of the organic matrix in

Editorlal responsibility: Otto Kinne (Editor),

Oldendorf/Luhe, Germany the otolith of the teleost fish Fundulus heteroclitus (Linnaeus) and Tilapia Nilotica (Linnaeus). J Exp Mar Biol Ecol 58:127-134

Wright PJ (1991) Calcium binding by soluble matrix of the otoliths of Atlantic salmon, Salmo salar L. J Fish Biol 38: $625-627$

Wright PJ, Rowe D. Thorpe JE (1991) Daily growth increments in the otoliths of Atlantic salmon parr (Salmo salar L.) and the influence of environmental factors on their periodicity. J Fish Biol 39:103-113

Wright PJ, Talbot C. Thorpe JE (1992) Otolith calcification in Atlantic salmon parr, Salmo salarl. and its relation to photoperiod and calcium metabolism. J Fish Biol 40:779-790

Zhang Z, Runham NW (1992) Temporal deposition of incremental and discontinuous zones in the otoliths of Oreochromis niloticus (L.). J Fish Biol 40:333-339

Submitted: March 3, 1999; Accepted: April 23, 1999 Proofs received from author(s): December 27, 1999 